\title{
PANCASILA DITEKAN, GEREJA TERTEKAN
}

\author{
Marthin S. Lumingkewas, ${ }^{1 *}$ Youke L. Singal, ${ }^{2}$ Roce Marsaulina, ${ }^{3}$ Stenly R. Paparang ${ }^{4}$ \\ ${ }^{1234}$ Sekolah Tinggi Teologi Moriah, Tangerang \\ Email: marstev100@gmail.com*
}

\begin{abstract}
From time to time Pancasila has always been the main topic in national issues in Indonesia. Since it was formulated and used as a state ideology that embraces and protects all interests and groups in Indonesia by Bung Karno, Pancasila has never been free from interests. Bung Karno and Suharto used Pancasila as a tool to deomolished Indonesian extrems religious and marxism groups. In the end, those groups gave antipasti against Pancasila and wanted to replace the ideology which was the result of the compromise of the nation's children to be replaced with sharia ideology which only represented certain groups. Even though the Jakarta charter agreement has been finalized, it does not become part of the five principles of Pancasila, but efforts to overthrow Pancasila as the state ideology continue to this day. Pressure on Pancasila; especially the undermining of the first precepts, it turns out to have an impact on the church which has to experience intimidation, threats and violence as the end result of intolerance of religious freedom. The purpose of this study is to provide an overview through social studies how the pressure on Pancasila affects the existence and operations of the church in Indonesia. It is hoped

that by using this methodology or social study, adequate results or descriptions of how the church takes political, ethical and concrete steps in addressing this situation are expected.
\end{abstract}

Keywords: pancasila, religious, intolerance

\begin{abstract}
Abstrak
Dari waktu ke waktu Pancasila selalu menjadi topik utama dalam isu nasional di Indonesia. Semenjak dirumuskan dan dipergunakan sebagai ideologi negara yang merangkul dan mengayomi seluruh kepentingan dan golongan di Indonesia oleh bung Karno, Pancasila ternyata tidak pernah bebas dari kepentingan. Bung Karno dan Soeharto menggunakan Pancasila sebagai alat pukul bagi kelompok kanan dan kiri Indonesia. Pada akhirnya kelompok tertentu memberikan antipasti terhadap Pancasila dan ingin menggantikan ideologi yang merupakan hasil kompromi anak bangsa digantikan dengan ideologi syariah yang hanya mewakili golongan tertentu saja. Walaupun telah final kesepakatan piagam Jakarta tidak menjadi bagian dari lima dasar Pancasila, namun upaya-upaya mendongkel Pancasila sebagai ideologi negara terus bergulir sampai saat ini. Tekanan terhadap Pancasila; khususnya rongrongan terhadap sila pertama, ternyata berimbas terhadap gereja yang harus mengalami intimidasi, ancaman dan kekerasan sebagai hasil akhir dari intoleransi kebebasan beragama. Tujuan dari penelitian ini untuk memberikan gambaran melalui kajian sosial bagaimana tekanan terhadap Pancasila berimbas pada eksistensi dan operasional gereja di Indonesia. Diharapkan dengan mempergunakan metodologi atau kajian sosial ini diperoleh hasil atau
\end{abstract}


deskripsi memadai bagaimana gereja melakukan langkah-langkah politis, etis dan konkrit dalam menyikapi keadaan ini.

Kata kunci: pancasila, religius, intoleransi

\section{PENDAHULUAN}

Indonesia yang menyatakan kemerdekaannya tahun 1945 memiliki UUD 1945 sebagai dasar konstitusi dari keberagaman yang mempersatukan dengan Pancasila yang menjadi ideology bangsa. Lima dasar yang terkandung dalam Pancasila merupakan pilar-pilr yang menyatakan azas kepercayaan kepada Tuhan, kemanusiaaan, rasa nasionalisme, kerukunan bersama dan keadilan. Sila pertama yang menyatakan "ketuhanan yang maha esa" merupakan pengakuan terhadap semua agama yang ada di Indonesia; pengakuan terhadap kepercayaan apapun yang dianut oleh setiap individu di bumi nusantara.

Pancasila yang menjadi aspirasi bagi kesatuan Indonesia merupakan tolak ukur kesatuan atau keberadaan sosial seseorang dalam kaitannya dengan orang lain; khusunya bagaimana mereka hidup dan saling berinteraksi satu dengan lainnya. Sebagai pengikat sosial masyarakat, Pancasila tidak pernah lepas dari penolakan dan penerimaan sepanjang sejarah berdirinya bangsa Indonesia.

Dalam sejarah penyusunan dan pengesahan Pancasila sebagai dasar negara, kita menemukan argumentasi dan debat panjang antara kaum konservatif dan religius, atau antara kaum sekuler dan Islam yang dicatat sejarah. Sebagai hasilnya, Pancasila yang kita kenal saat ini merupakan hasil kompromi antara kedua golongan yang berbeda di atas. Pancasila menjadi instrument penting dalam memberikan ruang bagi agama untuk berkembang, sekaligus sebagai alat untuk menciptakan kesatuan dan persatuan dari beragam suku dan kultur yang telah hadir sejak Nusantara tercipta - dan menjadi batu pengukur bagi segala torehan keadilan dalam masyarakat Indonesia.

Dalam perjalanan sejarahnya, kita melihat Pancasila telah mengalami beragam ujian dan tantangan yang pada akhirnya menciptakaan pemahaman sekaligus implementasi berkabut dalam masyarakat Indonesia dikarenakan penafsiran atas sila-sila yang terkandung didalamnya dibalut oleh beragam kepentingan pribadi dan golongan. Dalam sejarah kepemimpinan Sukarno, Pancasila digunakan sebagai alat untuk membungkam dan menekan segala bentuk aktivitas Islam yang dalam pemandangan Sukarno ekstrem dan berbahaya. 
Sedangkan dalam era Orde Baru yang dipimpin Soeharto, Pancasila dipergunakan sebagai alat untuk mencari dukungan serta mengembangkan Islam sekaligus menjadi doktrin dalam menekan kelompok Islam yang dipandang berbahaya. Sejarah juga mencatat ideologi negara ini dipergunakan sebagai alat untuk membatasi; bahkan melarang aktifitas dan beroperasinya bentuk agama lain di Indonesia. Dari gambaran ini kita melihat ideologi bangsa Indonesia yang terekam dalam Pancasila - yang berfungsi sebagai alat pembentuk identitas dari kelompok atau bangsa; atau sebagai alat persatuan dan kesatuan Manusia Indonesia dari beragam etnis dan agama; sekaligus sebagai tameng solidaritas; ternyata tidak terlihat dalam perkembangan sejarahnya di Indonesia. Semua pembatasan dan legalisasi kepentingan yang menggunakan Pancasila sebagai alat mencapai tujuan di atas berhasil melemahkan Pancasila sebagai ideologi yang mengedepankan harmoni dan kebebasan dalam beragama.

\section{METODE}

Penelitian merupakan suatu upaya manusia untuk mengetahui berbagai hal yang belum diketahui, atau sudah diketahui tapi belum diyakini kebenarannya. Untuk itulah maka dilakukan serangkaian kegiatana yang disebut penelitian. Dalam konteks ilmiah, penelitian haruslah memenuhi berbagai ketetentuan atau prosedur akedmik. Dalam penelitian ini penulis mempergunakan metodologi penelitian sosial sebagai pendekatan utama untuk membahas keterkaitan antara Pancasila dengan pluralism beragama di Indonesa; khususnya mempelajari gejala atau fenomena sosial yang terjadi di dalam masyarakat. Analisis deskriptif yang memberikan penjabaran detil dalam penelitian ini berupaya menjawab fenomena sosial tekanan yang dialami Pancasila dalam kaitannya dengan keberagaman atau pluralitas beragama di Indonesia.

Metode yang dipakai dalam penelitian ini adalah metode kualitatif; yaitu metode yang melakukan riset dengan memanfaatkan data deskriptif berupaka kata-kata tertulis atau lisan dari orangorang dan pelaku yang diamati (konsep ristekdikti). Prosedur yang dilakukan dalam metode ini adalah menyusun asum dasar yang digunakan kemudian ditafsirkan.

\section{HASIL DAN PEMBAHASAN}

\section{Dasar Negara Indonesia}

Negara Indonesia yang memiliki kurang lebih 17.500 pulau yang tersebar dari Samudera India sampai dengan 
Samudera Pasifik, menempatkan bangsa ini sebagai negara dengan jumlah pulau terbanyak di dunia. Negara besar dengan jumlah penduduk tahun 2016 sekitar 260 juta jiwa, memiliki moto nasional yang dikenal dengan Bhineka Tunggal Ika simbol yang meniscayakan hadirnya pluralitas etnis dan agama yang dianut dan diakui negara Indonesia. Nasionalisme Indonesia terekam dalam Pancasila yang memuat lima prinsip negara:

1. Ketuhanan Yang Maha Esa

2. Kemanusiaan Yang Adil Dan Beradap

3. Persatuan Indonesia

4. Kerakyatan Yang Dipimpin Oleh Hikmat Kebijaksanaan Dalam Permusyawaratan Perwakilan

5. Keadilan Bagi Seluruh Rakyat Indonesia

Lima Prinsip di atas merupakan ideologi bangsa Indonesia yang termasuk di dalamnya gagasan-gagasan, ide-ide, dan segala bentuk keyakinan dari berbagai bidang kehidupan Manusia. Dengan kata lain ke lima Sila dari Pancasila menekankan pada: percaya kepada allah, kemanusiaan, nasionalisme, demokrasi dan keadilan sosial. Semua ini merupakan bentuk 'berbagi nilai-nilai' yang menekankan pada sekularisme, pluralisme dan masyarakat beragama yang penuh toleransi yang dirangkum dalam nilai-nilai tertentu seperti: pertama, nilai ketuhanan yang berperi kemanusiaan, persatuan, kerakyatan dan keadilan. Kedua nilai spiritual, ideal, dan pragmatis, ketiga nilai etis, nilai sosial dan logis. ${ }^{1}$

Prinsip pertama dari Pancasila merupakan rekayasa kompromi dalam suatu pengakuan bahwa agama memainkan tempat utama dalam masyarakat Indonesia - sekaligus menolak secara eksplisit bentuk negara Islam. Merupakan usaha untuk memenuhi pengharapan dan sekaligus memuaskan kaum konservatif dan sekuler. Ideologi yang memberikan ruang terhadap penyembahan akan pribadi yang dipandang sebagai pencipta alam semesta dan Manusia ini sekaligus tidak memberikan ruang terhadap merekamereka yang agamanya tidak masuk dalam pengakuan negara Indonesia - juga diskriminasi terhadap pribadi maupun kelompok orang yang tidak mengakui satupun model penyembahan teistik yang dianut Indonesia; yang kita kenal dengan sebutan ateis.

Warna dari masyarakat Asia yang pada umumnya berbeda dalam kultur, etnik dan agama dalam wilayah atau negara mereka masing-masing; termasuk Indonesia, memaksa para bapa bangsa

\footnotetext{
${ }^{1}$ Widjaya. (2004), Pendidikan Kewarganegaraan, (Bandung, PT RafikaAditama), 6.
} 
merumuskan satu formula yang disebut "kesatuan dan persatuan" sebagai perekat sekaligus pembeda di antara masyarakat. Pancasila juga dikenal sebagai salah satu dari "Empat Pilar" kehidupan nasional bersama-sama dengan "Bhineka Tunggal Ika, Undang-Undang Dasar 1945 dan Negara Kesatuan Republik Indonesia.” Prinsip kesatuan yang dimiliki Pancasila ini kemudian mendapat kekuatan tambahan dari lagu kebangsaan Indonesia; Indonesia Raya, yang ditulis oleh W.R. Supratman. Pada akhirya kita melihat Pancasila membentuk dasar dari konstitusi negara yang menyatakan hadirnya kebebasan dalam beragama; yang tercatat dalam pasal 28 Undang-Undang Dasar 1945.

\section{Tekanan Terhadap Pancasila}

Kesatuan dan persatuan Indonesia telah mengalami ujian berkali-kali dalam sejarahnya. Ujian pertama adalah pemberontakan yang terjadi dari beberapa golongan yang menolak Pancasila sebagai dasar negara seperti yang muncul dalam wajah Darul Islam yang berperang untuk mendirikan negara Islam Indonesia dari periode 1950-1959. Rupanya tidak semua golongan masyarakat dapat menerima roh pluralisme yang terkandung dalam konstitusi negara tersebut; utamanya beberapa kelompok Islam - entah siapa mereka atau apa doktrin yang dimiliki satu dengan lainnya - telah berusaha keras untuk mewujudkan mimpi mendirikan negara Islam di Indonesia. Selain Darul Islam, kita juga melihat partai Masyumi, Hisbut Tahrir Indonesia dan front pembela Islam; ormas yang menggunakan cara-cara radikal - mewarnai upaya mendongkel Pancasila sebagai dasar dan ideologi negara.

Periode 1955-1959 merupakan periode pendek dari sistem politik demokrasi yang dianut Indonesia sejak menyatakan kemerdekaannya pada tahun 1945. Periode ini merupakan momen kritis dari institusi negara-agama Indonesia, yang ditandai munculnya banyak partai dalam parlemen yang menuntut membentuk konstitusi baru, salah satunya adalah materi hubungan negara-agama yang diusung Indonesia. ${ }^{2}$ Partai-partai nasionalis yang memegang peran utama dalam periode ini adalah Patai Nasionalis Indonesia (PNI), Masyumi dan NU yang mewakili kelompok Islam, serta Partai Komunis Indonesia (PKI). Jika memperhatikan ideologi dari masingmasing partai di atas, maka Masyumi dan NU pastilah menempatkan diri mereka sebagai pendukung berdirinya negara

\footnotetext{
2 Capoccia, G., \& Kelemen, R. D. "The study of critical junctures: Theory, narrative, and counterfactuals in historical institutionalism." World Politics, 59 no.3 (2007): 344-348
} 
Islam, sedangkan Partai Nasional Indonesia merupakan pendorong terciptanya negara agama yang netral; yang menampung semua aspirasi masyarakat Indonesia. Ide negara netral religius yang diusung PNI menekankan terbentuknya negara yang tidak berdasarkan pada azas Islam yang menjadi kelompok mayoritas Indonesia. Melainkan negara harus bersikap inklusif dalam prinsip kenegaraan dengan mempertahankan Pancasila sebagai model utama - sekaligus netral daripada Islam. Konsep yang sudah pernah disusun dan disepakati pada tahun 1945 sebagai perwujudan dari kesatuan nusantara yang diminta oleh masyarakat wilayah Indonesia Tengah dan Timur; serta Sumatra saat itu.

Sejarah mencatat situasi parlemen yang melakukan rerferendum untuk mengganti Pancasila sebagai dasar dan ideologi negara saat itu tidak membuat keputusan apapun dikarenakan kekuatan suara Masyumi dengan PNI tidak jauh berbeda. Deadlock yang terjadi otomatis tidak membuka ruang bagi penghapusan Pancasila sebagai dasar dan ideologi negara. Tidak adanya keputusan final dari para anggota parlemen mendorong presiden Soekarno membubarkan parlemen. Tindakan pembubaran parlemen ini dilanjutkan dengan mempertahankan konstitusi negara dan Pancasila sebagai dasar negara daripada menggantinya dengan model negara berdasarkan Islam. Kekalahan kelompok Islam yang hendak mendirikan negara Islam saat itu lebih disebabkan Partai Komunis Indonesia memberikan suaranya kepada PNI; dengan kata lain PKI melakukan Koalisi dengan PNI untuk menghadang pergerakan koalisi Islam saat itu. Manuver yang dilakukan PKI dalam mendukung PNI tentunya di luar dugaan semua pihak disebabkan dari semula PKI digadang-gadang memberikan suaranya pada partai yang mengusung platform ekonomi; partai Murba misalnya. Apakah saat ini kita melihat ada kelompok tertentu begitu gencarnya mendengungkan "waspada PKI" sebagai bentuk atau ekspresi tidak senang atas koalisi PKI dengan PNI tahun 1955, ataukah ada agenda lain, penulis belum menemukan jawabanya. Yang pasti kita melihat kelompok Islam gagal mengganti Pancasila sebagai dasar dan ideologi negara - sekaligus presiden Soekarno berhasil mempertahankan Pancasila dan UUD 45 sebagai fondasi negara dengan membubarkan parlemen terlebih dahulu. Hal ini mengakhiri perdebatan tahun 19551959 mengenai apakah negara akan berakhir dalam bentuk negara Islam ataukah dalam formulasi Pancasila yang 
tidak sekuler ataupun Islamik. Dalam fase ini, Pancasila keluar sebagai pemenang walau ditekan sedemikian rupa.

Kegagalan pemberontakan PKI pada tahun 1965, yang justru membawa Soeharta sebagai presiden dan penguasa Indonesia selama 32 tahun, telah membawa perubahan sekaligus tekanan dalam bentuk lain terhadap Pancasila. Frasa 'Orde Baru' yang dilahirkan dan dikembangkan pada era Soeharto memberikan ruang besar bagi perkembangan pluralis dan masyarakat sekuler sekaligus menekan kelompok Islam tertentu. Menurut Michael Buehler, ${ }^{3}$ Presiden Soeharto walaupun pada era pemberontakan Partai Komunis Indonesia menggunakan dan sangat bergantung pada kelompok atau partai-partai Islam yang ada saat itu sebagai palu pemukul pemberontakan, namun sang Presiden pada dasarnya memberikan ruang yang sangat kecil bagi agama untuk berkembang dalam negara. Soeharta hanya mengijinkan satu partai Islam beroperasi sebagai wadah aspirasi kaum Islam dalam masa kekuasaannya. Partai Islam ini harus berjuang dengan partai nasionalis yang berada dibawah komando para penerus ide bung Karno dalam diri Partai Demokrasi

${ }^{3}$ Michael Buehler, 'The Politics of Shari'a Law: Islamist Activities and the State in Democratizing Indonesia, (London: Cambridge University Press, 2016), 9-42.
Indonesia. Untuk menjegal kelompok atau partai lain berkuasa, Soeharto menggabungkan militer dengan partai Golkar serta membentuk keduanya menjadi elemen politik yang sangat kuat sekaligus sekuler. Penggabungan militer dengan Golkar berhasil menjaga kekuasaan Soeharto selama lebih dari tiga dekade; sekaligus menjadikan Pancasila sebagai ideologi yang melegalkan tekanan, ancaman dan paksaan kepada masyarakat melalui militer dan Golkar.

Bagi Soeharto, segala bentuk oposisi tidak mendapat ruang toleransi dalam khazanah politiknya. Semua elemen masyarakat yang muncul dalam organisasi-organisasi - apapun bentuknya, harus menerima Pancasila sebagai satusatunya prinsip dalam organisasi. Isu-isu sensitif seperti pelanggaran etnik dan agama dilarang masuk dalam ruang publik. Dalam hal ini militer memainkan peran utama dalam pengawasan. Unit-unit rahasia masuk dalam setiap level masyarakat dan organisasi dari pusat sampai daerah. Namun pada era ini, kestabilan politik dan ekonomi merupakan poin penting yang tidak dimiliki pada era manapun; termasuk periode ini yang dipenuhi dengan propaganda-propaganda yang mendeskreditan agama, suku dan golongan tertentu dalam upaya mewujudkan keinginan sebagian 
masyarakat Indonesia dalam mendirikan negara khilafah - juga ditenggarai adanya kepentingan ekonomi yang tersumbat dari kelompok tertentu pada masa pemerintahan Jokowi saat ini. Model pemerintahan represif otoritarian yang dibangun dan dikembangkan Soeharto, ternyata berdampak pada kestabilan politik dan ekonomi. Harga-harga bahan pokok umumnya terjangkau masyarakat, tingkat ekonomi cenderung meningkat dari tahun ke tahun. Pemerintah tidak melepas harga di pasar, kontrol harga barang dan jasa dilakukan oleh negara. Program Repelita yang menjadi program unggulan Soeharto dalam membangun negeri mampu mensejahterakan masyarakat; walaupun tidak bisa kita pungkiri, pulau Jawa selalu mendapat porsi terbesar dalam perhatian maupun anggaran pembangunan.

Soeharto dapat dikatakan sukses dalam upaya membungkam semua suara yang mencoba mendongkel Pancasila dalam versinya; termasuk upaya mendirikan negara Islam Indonesia. Tidak ditemukan adanya aktivitas atau peristiwa besar semenjak Soeharto berkuasa sampai dengan kejatuhannya merupakan bukti sejarahnya. Pancasila menjadi azaz tunggal untuk membungkam dan memberangus para oposisi yang menggunakan bendera komunis dan Islam. Pada era ini muncul kalimat ekstrimis kiri
- para pendukung komunis dan ektrimis kanan - para pendukung Islam radikal. Menurut Donald Weatherbee, kedua kelompok ekstrem tersebut terikat satu dengan lainnya. Dan untuk membungkam para ekstrimis ini, Soeharto percaya membangun negara yang stabil merupakan satu-satunya cara. ${ }^{4}$

Dari gambaran di atas, kita melihat Pancasila bertransformasi sebagai alat sosial dalam menjangkau masyarakat atau sebagai kepanjangan tangan pemerintah dalam memberikan pengaruh serta upaya implementasi kebijakan, sekaligus sebagai jaminan pemerintahan Soeharto terus bertahan. Model atau pola Pancasila yang diusung Soeharto ini tentunya memiliki konsekuensi berbeda dengan apa yang pernah dipikirkan bung Karno dan Mohammad Yamin. Bangunan Pancasila Soeharto memiliki pilar pluralisme dan kontrol ketat negara atas agama, serta negara lebih utama atau lebih penting daripada hak warga negaranya.

Politik otoritarian Soeharto yang banyak melakukan pelanggaran hak asasi Manusia, korupsi yang merajalela dalam lingkup Cendana dan sekutunya, membawa pada kejatuhan dan kehancuran era Orde Baru pada tahun 1998. Bersamaan dengan kejatuhan Soeharto,

${ }^{4}$ Donald E. Weatherbee, "Indonesia in 1984: Pancasila, Politics, and Power." Asian Survey 25, no. 2 (1985): 189. 
kita melihat negara kembali masuk dalam ujian besar. Lahir dan hadir dalam jumlah besar anggota masyarakat dan golongan yang tidak memberikan porsi besar terhadap Pancasila sebagai ideologi dan dasar negara disebabkan manipulasi Pancasila pada era Soeharto. TNI yang selama ini menjadi pendukung utama Soeharto kehilangan kekuatannya; bahkan dicabut hak politiknya di DPR. Fungsi ganda TNI ditekan dan Pancasila menjadi sebatas slogan tidak berarti. TNI yang selama ini menjadi penjamin stabilitas dan politik dan sosial negara kehilangan fungsinya. Hal ini semakin diperparah dengan tidak hadirnya pemimpin kuat seperti Sukarno dan Soeharto yang menjadi nahkoda perahu Republik Indonesia. Para pemimpin yang hadir setelah era Soeharto terguling tidak memiliki kemampuan kepemimpinan yang baik, korupsi tetap merajelala di manamana, kebijakan politik tidak jelas, birokrasi menjadi semerawut dan diperjelas dengan agenda-agenda politik dari banyak kelompok yang berdiri di atas kepentingan dan golongannya.

Tergulingnya Soeharto membawa Indonesia masuk ke dalam bentuk negara tidak teratur dan tidak stabil yang bermuara pada kehancuran negara. Kejahatan dan kekerasan politik, etnis dan agama muncul seperti jamur di musim hujan plus minus hadirnya tindakan preventif dan represif aparat keamanan. Tokoh-tokoh Islam radikal yang pada era Soeharto melarikan diri ke luar negeri, kembali ke Indonesia dengan tetap mengusung ideologi lama yang pernah dianuntnya. Orang atau kelompok orang ini tentunya tidak berada dalam kerangka ideologi Pancasila; sekaligus terbebas dari kemungkinan ancaman dan tindakan preventif militer. Dalam perjalanan kelompok radikali ini kita melihat mereka melancarkan agresi keras kepada pemeluk agama lain dan kelompok Islam sendiri yang tidak mengikuti dogma fundamentalis yang mereka anut. Kelompok ini kita kenal sebagai Jemaah Islamiah, Majelis Mujahidin Indonesia, Hizbut Tahrir Indonesia dan Front Pembela Islam yang dipimpin oleh Riziek Shihab. Fundamentalisme yang di anut oleh kelompok radikal ini pada akhirnya bermuara pada pemboman di berbagai tempat di Indonesia; seperti di Bali, penutupan banyak gereja, atau pemberian label sesat kepada kelompok Islam Ahmadiyah - yang bahkan mendapat dukungan dari MUI.

Upaya-upaya untuk mendongkel Pancasila dari ranah Indonesia bukan saja dilakukan dalam tindakan-tindakan kekerasan di atas. Terbukti ada upaya konstitusional yang dilakukan untuk 
mendongkel dasar negara tersebut hilang atau berkurang kekuatannya di Indonesia melalui amandemen UUD 45. Kebebasan berbicara yang selama ini hilang pada era Soeharto dan muncul setelah ia terguling dari tampuk pemerintahannya berujung pada kesadaran diri kelompok tertentu untuk mengganti konstitusi negara yang menurut mereka selama ini dipergunakan sebagai alat pemukul dan membungkam mulut mereka. Wacana perubahan konstitusi negara mulai muncul pada tahun 1999; utamanya revisi UUD 1945 pasal 29. Tentunya kelompok Islam kembali berupaya memasukkan 7 kata dalam piagam Jakarta yang pernah dihilangkan sebagai bentuk kompromis dengan kepercayaan lain.

Kelompok non Islam tentunya keberatan dengan ide memasukkan kembali 7 kata piagam Jakarta dalam konstitusi negara. Ide memasukkan ke tujuh kata piagam Jakarta akan menciptakan kehancuran negara kesatuan Negara Republik Indonesia menjadi hilang. Kelompok Kristen tidak ingin membuka ruang argumentasi mengenai Piagam Jakarta yang telah ditutup pada tahun 1945. Jika dibuka kembali, maka mereka dan banyak daerah Indonesia memilih memisahkan diri dari NKRI. Menurut Denny Indrayana, Kementerian Agama (saat itu Departemen
Agama) memberikan argumentasi bahwa pasal 29 UUD 1945 yang diupayakan diamandemen harus dipertahankan orisinalitasnya dengan tiga alasan: pertama, pasal ini merupakan hasil dari konsensus nasional dari para pendiri bangsa; kedua, pasal ini melayani sebagai faktor pemersatu bangsa dan jika diubah, bangsa akan disintegrasi; ketiga, bunyi dan tindakan pasal ini merupakan bentuk kompromi dari seluruh sistem agama bangsa. ${ }^{5}$ Amandemen pasal 29 UUD 1945 akan membawa hegemoni kekuasaan Islam atas Indonesia yang akan berujung kepada kekacauan dan disintegrasi bangsa dalam skala luas.

Dalam skala lokal, tantangan terhadap ide kesatuan yang dimiliki Pancasila selain mendapat tekanan dari kelompok-kelompok radikal Islam yang berupaya mendirikan negara khilafah dengan tindakan terror terhadap pemeluk agama lain atau terhadap sesamnya yang tidak mengikuti doktrin fundamentalis yang mereka miliki, juga muncul dalam bentuk kerusuhan-kerusuhan lokal antar suku dan antar agama di beberapa daerah Indonesia. Kerusuhan Dayak dengan Madura tahu 2000-2001paling tidak telah merenggut korban jiwa dari kedua pihak di

\footnotetext{
5 Denny Indrayana. Indonesian Constitutional Reform 1999-2002: An Evaluation of Constitution Making in Transition. PhD diss., Melbourne: University of Melbourne, 2005.
} 
mana sekitar 5000 orang tewas dan ratusan ribu orang Madura melarikan diri dari Kalimantan. Kekuatan karismatik dan bentuk negara kuat yang dimiliki Soeharto dan tidak dimiliki oleh para pemimpin negara kemudian hari, telah merusak sekat-sekat kesatuan dan persatuan yang walaupun mendapat bumbu 'takut', namun mampu menjamin absennya kerusuhan di Indonesia era Soeharto. Kerusuhan Dayak dan Madura tampaknya berakhir dengan sendirinya. Kebijakan pemerintah saat itu yang kurang kuat yang mungkin disebabkan wilayah ini tidak masuk dalam prioritas politik, menjadikan kedamaian yang hadir saat ini rawan konflik hadir kembali.

Kerusuhan selanjutnya yang muncul dan lebih mengkhawatirkan lagi terjadi di Ambon dan Poso; di mana kerusuhan ini mendapat bahan bakar dari perbedaan kepercayaan antara Kristen dan Islam. Dalam kedua kerusuhan besar ini, tidak kurang 20.000 orang; dari Kristen dan Islam tewas dan hampir satu juta orang kehilangan tempat tinggalnya. Militer terkesan terbagi dua kelompok dalam mengatasi kerusuhan ini. Bahkan laskar jihad yang datang ke Maluku untuk membantu saudara-saudara mereka dalam apa yang mereka sebut sebagai "perang suci" difasilitasi oleh elemen TNI dalam perjalanan dan perjuangannya. Tujuan dari laskar jihad ini adalah membunuh orang Kristen, memaksa memeluk agama Islam, atau menghilangkan mereka. ${ }^{6}$

Sebagaimana biasa, beberapa teori konspirasi bermunculan. Beberapa kaum demokrat melihat ada tangan tidak terlihat militer dalam upaya menciptakan kegoncangan dalam pemerintahan sipil yang ada. Beberapa kelompok Kristen di Timur kuatir kasus Maluku dapat menjadi landasan Muslim untuk mentransformasi seluruh wilayah Timur. Namun pada dasarnya Weatherbee melihat multiagenda lahir dalam kerusuhan ini. $^{7}$ Pancasila yang memiliki agenda pluralis dan unity; termasuk di dalamnya mendukung hak kaum minoritas, menghilang dalam tataran politik dan masyarakat demokrasi Indonesia pasca Soeharto. Para pemangku kebijakan politik; di Jawa khususnya tidak mampu mengambil resiko kehilangan pendukung mayoritasnya untuk mendukung kebijakan minoritas.

Pancasila yang seharusnya menjadi dasar pemersatu negara, mendapat tekanan hebat pasca kejatuhan Soeharto. Agendaagenda konstitusi di luar Pancasila terus diupayakan masuk menggantikan dasar dan ideologi negara yang telah disusun

${ }^{6}$ Donald E. Weatherbee. Indonesia: Political Drift and State Decay, The Brown Journal of World Affairs IX, no.1 (2002): 27.

${ }^{7}$ Donald E. Weatherbee. Indonesia, 27. 
oleh para pendiri bangsa ini. Pada tanggal 1 Juni 1945 Sukarno berbicara mengenai Indonesia baru harus berada dalam posisi antara negara sekuler dan negara yang berdasarkan agama. Untuk itu ia memformulasikan doktrim mengenai Lima Pilar Kebangsaan di mana Pancasila bukan saja percaya kepada Satu Ilah Utama, tetapi juga nasionalisme, humanisme, demokrasi dan keadilan sosial. Kotbah Sukarno ini kemudian menandai hari lahirnya Pancasila. Menurut Sukarno, ia tidak membangun atau menemukan doktrin tersebut, tetapi menemukannya dengan melihat dalam setiap jiwa masyarakat Indonesia. ${ }^{8}$ Dengan ini Sukarno mencoba menjelaskan bahwa Pancasila merupakan warisan budaya bangsa Indonesia yang sudah hadir sejak Nusantara hadir.

Kepercayaan kepada satu ilah maha tinggi mengandung arti bahwa setiap warga negara wajib percaya kepada allahnya masing-masing. Orang Kristen wajib percaya dan menyembah kepada Yesus; Muslim wajib mengikuti ajaran nabi Muhammad; Budha harus mengikuti ibadah mereka menurut kitab sucinya. Semua harus memiliki kepercayaan kepada allah. Negara Indonesia harus menjadi negara di mana setiap orang dapat

${ }^{8}$ B.J. Boland. The Struggle of Islam in Modern Indonesia, (The Hague: Martinus Nijhoff, 1971), 21-22. menyembah allah dengan bebas, tanpa egoisme religious. Mari kita mempelajari agama kita, mari kita mempraktekkan agama kita, apakah saudara Islam atau Kristen, dalam masyarakat sipil, harus ada penghormatan satu dengan lainnya dalam cara dan arah yang sama. ${ }^{9}$

\section{Implikasi Tekanan Terhadap Pancasila Bagi Gereja Indonesia}

Sejak Indonesia menyatakan kemerdekaanya pada tahun 1945, kebhinekaan Indonesia tidak berjalan mulus. Pluralisme beragama mengalami tekanan-tekanan; baik yang dilakukan oleh gerekan massa maupun serangkaian regulasi yang dikeluarkan pemerintah (misalnya SKB 3 Menteri tentang pendirian rumah Ibadah) yang membawa gelombang intoleransi beragama. Muncul dan bangkitnya arus utama islam konservatif yang misalnya diwadahi oleh ormas Front Pembela Islam atau Hizbut Tahrir Indonesia, semakin memperkeruh ruang intoleransi di Indonesia - khususnya berkenaan dengan agama-agama minor; seperti Kristen.

Upaya-upaya menghapus jejak nasionalisme Indonesia terus dilakukan semisal membuat beberapa sekolahsekolah negeri (SD, SMP, SMU) memiliki

9 Kahin, George McTurnan. Nationalism and Revolution in Indonesia, (Ithaca, NY: Cornell University Press, 1952), 125. 
label agama tertentu. Bahkan pada tahun 2021 terjadi kasus menarik sekaligus membuat miris rasa nasionalisme bangsa ketika siswi-siswi non-muslim di satu daerah di Padang Sumatera Barat diwajibkan berjilbab.

Penulis melihat resistensi yang dilakukan oleh konservatif Islam terhadap Kristen yang terjadi 20 tahun terakhir ini memiliki kolerasi dengan ide penginjilan dan kebangkitan Karismatik Pentakosta Indonesia. Perkembangan kekristenan secara global; termasuk Indonesia di dalamnya menciptakan arus baru dalam kekristenan yang berbeda dengan aliran gereja arus utama yang sudah hadir sejak jaman penjajahan Belanda. Gerakan Karismatik Pentakosta yang berkembang ini sangat menekankan kepada karuniakarunia, iman, mujizat atau hal-hal supranatural - sekaligus sering mengabaikan segala bentuk dokma atau kredo yang selama ini dipergunakan dan dijalankan jemaat dalam gereja-gerja arus kuat.

Kebangkitan karismatik yang memberikan semacam perlawanan terhadap segala bentuk sekularisme; paham yang menisbikan agama ke dalam urusan politik, negara atau institusi publik, berkembang dengan subur di Indonesia; sekaligus kebangkitan gerakan ini menjadi simbol perlawanan terhadap kegagalan institusi agama dalam memenuhi kebutuhan umat; utamanya kebutuhan emosi jemaat yang selama ini dijejeali dengan serangkaian dogma dan aturan kaku yang tidak memberikan kemaslahatan umat. Kehidupan dogmatiskaku, sekularisme yang merajelela disertai tekanan dari kelompok konservatif Islam semakin memperkuat perkembangan kelompok Kristen tertentu dalam konteks misi amanat agung di daerah urban Indonesia. Kekuatan dari ibadah-ibadah kolektif yang dilakukan; yang merupakan ekspresi dari beragam nilai, berhasil mempersatu kelompok - sekaligus komitmen dan rasa bersama di tengahtengah tekanan yang ada.

Tekanan yang dimaksud adalah bentuk perlawanan atau intoleransi dari kelompok Islam tertentu yang melihat dengan cemas perkembangan kuantitas Kristen sebagai hasil dari kristenisasi. Ide adanya "kristenisasi" terus dihembuskan dengan intens sebagai upaya diskriminasi dan intoleransi untuk membatasi gerakan dan perkembangan Kristen di Indonesia. Intoleransi ini tidak pernah berakhir walaupun sudah pernah ada kesepakatan final tentang ayat-ayat yang kemudian menjadi dasar Pancasila terlepas dari kepentingan golongan tertentu yang berupaya memasukkan klausa piagam Jakarta. Upaya-upaya ideologisasi 
kelompok Islam tertentu yang berupaya membangun negara Islam Indonesia terlihat tidak berkesudahan; bahkan seringkali dilakukan dengan kekerasan berupa pelarangan pendirian rumah ibadah atau perusakan rumah ibadah.

Tekanan-tekanan yang muncul dari kelompok Islam tertentu terhadap gereja melahirkan diversifikasi dogma sebagai upaya adaptasi atau kontekstual yang khas dari kaum ekumenikal. Kaum ekumenikal yang tetap mengusung misi amanat agung untuk memberitakan injil ke seluruh bumi membangun bangunan teologi yang lebih konstruktif, pluralis dan kontekstual. Doktrin yang dibangun ekumenikal ini tetap memberikan ruang bagi perbedaan sebagai upaya melestarikan nilai-nilai Pancasila. Sedangkan kaum Karismatik Pentakosta yang sangat khas dengan karunia-karunia roh, mujizat, dan pelayanan iman, terlihat sangat menekankan pada penginjilan atau penjangkauan jiwa. Bagi kaum Karismatik, kaum ekumenikal telah menelantarkan ide penjangkauan jiwa yang merupakan roh dari kekristenan. Ekumenikal dalam hal ini memberikan ruang kompromi dan toleransi yang menutp peluang keselamatan bagi orang di luar Kristen. Iman yang merupakan tonggak orang percaya telah digantikan dengan doktrin tentang keadilan dan kedamaian semata dikarenakan keselamatan melulu karya absolut Allah dalam Yesus Kristus. Sedangkan bagi Karismatik Pentakosta, keselamatan merupakan upaya bersama Allah dan manusia dalam upaya menjangkau jiwa yang tersesat. Namun demikian, penulis melihat apapun kelompok, golongan atau denominasi gereja, Pancasila tetap menjadi satu-satunya azas bernegara yang wajib dipegang teguh dan dipertahankan, terlepas dari permasalahan yang diterima gereja karena tekanan yang diterima sebagai imbas dari tekanan yang diterima Pancasila atau melalui Pancasila tekanan muncul.

\section{KESIMPULAN}

Berbeda dengan situasi keagamaan Eropa dan Amerika, di Indonesia, agama tiap waktu terus mengalami penghargaan, terus meluaskan pengaruh dalam banyak elemen dan aspek masyarakat. Konsep Pancasila yang merupakan hasil konsensus anak bangsa pada tahun 1945, telah dipergunakan dengan beragam cara dan muatan kepentingan sejak diumumkan dan dijadikan dasar dan ideologi negara. Pancasila sering dipergunakan sebagai alat mengontrol beberapa manifestasi agama sekaligus mencegah konflik yang mungkin terjadi. Kepemimpinan negara yang berbeda, menghasilkan tafsir dan 
penggunaan Pancasila yang berbeda pula.

Hal ini dapat terlihat dari model kepentingan bung Karno, Soeharto, Megawati, Abdurahman Wahid, Susilo Bambang Yudhoyono dan Jokowi. Dari daftar presiden Indonesia tersebut, kita melihat ada presiden yang mempergunakan Pancasila sebagai alat politik dan ada yang mempergunakannya sebagai alat kemaslahatan bersama untuk mencapai keadilan, kesetaraan, kesejahteraan dan perdamaian.

Dalam sejarahnya Pancasila telah berkali-kali mengalami tekanan sebagai upaya menyingkirkan ideologi ini dari bumi Indonesia. Pemberontakan kaum Islam radikal seperti Kahar Muzakar yang berupaya mendirikan negara Islam Indonesia merupakan bukti nyata yang tidak dapat dibantah sejarah. Pancasila juga mendapat tekanan berupa penyimpangan ideal pada era Sukarno ketika dijadikan alat berangus bagi kelompok Islam radikal. Pada era Soeharto, Pancasila menjadi senjata untuk membungkam ekstrim kiri dan kanan sekaligus menjadi alat untuk menciptakan kestabilan politik di Indonesia.

Periode ketika Soeharto jatuh, Pancasila kembali mendapat tekanan; terutama dalam bidang kesatuan dan agama. Sektarian dan kebanggan etnik yang muncul menjadikan Pancasila tidak berfungsi sebagai alat pemersatu bangsa dan sebagai dasar penghormatan kepada kepercayaan lain. Munculnya kelompok Islam radikal yang seolah-olah lepas dari pengawasan pemerintah menjadikan republik ini penuh konflik agama semenjak tahun 1999 sampai dengan saat ini. Intoleransi berkembang luas tanpa kehadiran negara untuk menjamin hak warga negara yang terkandung dalam konstitusi. Pluralisme yang menjelma dalam kesatuan dan persatuan pada sila Pancasila, serta ke-Bhineka Tunggal Ika seolah-olah menjadi tidak berarti di bangsa Indonesia saat ini. kelompok- kelompok garis keras (fundamentalis) ini seolah tidak tersentuh pada era presiden tertentu, dan barulah pada era Jokowi, kaum intoleran ini; seperti Hizbut Tahrir Indonesia dan Front Pembela Islam dibubarkan. Bahkan para pemimpin mereka seperti Riziq dan Munarman ditangkap.

Dalam menghadapi tekanan ini, gereja-gereja Indonesia ternyata melakukan semacam adaptasi untuk mendapat jalan keluar. Ada gereja-gereja tertentu seperti ekumenikal yang terlihat pluralis dan kontekstual dengan tetap mempertahankan ide keragaman budaya dan kepercayaan sebagai bagian dari konsep berteologi untuk menciptkan shalom di bumi ini. di pihak lain ada aliran gereja yang dimotori oleh kaum 
Karimatik Pentakostal yang berupaya keluar dari sistem institusi gereja yang dianggap gagal membawa injil ke dalam dunia karena mereka telah anti scriptural atau menyesatkan umat dengan memberikan toleransi berlebih atau kebablasan sebagai akibat tekanan terhadap Pancasila yang berimbas tekanan terhadap gereja yang menempatkan Pancasila sebagai satu-satunya dasar atau azas bernegara di Indonesia.

Hal ini semakin diperparah ketika ada kelompok Islam tertentu yang melihat Kristen minoritas yang terus berkembang sebagai ancaman bagi mereka. Bagi mereka Pancasila memberikan ruang bagi perkembangan kekristenan sekaligus merongrong keberadaan Islam yang diklaim mayoritas. Memang tidak dipungkiri bahwa ideology Pancasila membuka ruang yang besar bagi kesatuan di bangsa ini dikarenakan Pancasila menjadi semacam pelindung dari diintegrasi keberagaman; sekaligus menjadi pintu bagi pemberitaan injil dalam ruang toleransi keberagamaan yang menjadi dasar pertama dari butir Pancasila.

\section{KEPUSTAKAAN}

Boland, B. J. The Struggle of Islam in Modern Indonesia, The Hague: Martinus Nijhoff, 1971.
Pancasila merupakan solusi unik bagi hubungan antara agama dan negara di Indonesia. Pancasila yang merupakan roh dari setiap warga negara Indonesia terbukti sangat adaptif dan fleksibel dipergunakan di Indonesia. Hubungan antara agama dan negara yang dikandung Pancasila pada akhirnya tidak pernah mendeklarasikan hadirnya agama mayoritas; sekaligus menyatakan bentuk agama lain bukanlah minoritas. Kebebasan beragama yang tidak pada tempatnya telah membawa kesengsaraan dan terror kepada pemeluk agama lain akhir-akhr ini. Ide pembentukan negara khilafah yang harus berbenturan dengan penganut kepercayaan lain menjadi buktinya. Bagi penulis, apabila Indonesia tidak mampu melepaskan kontrol negara terhadap agama; dalam hal ini dibuktikan dengan hadirnya Kementerian Agama, maka bangsa ini lebih baik mengikuti dan mengimplementasikan model "kontrol agama" yang pernah dipraktekkan oleh Soeharto.

Buehler, Michael. 'The Politics of Shari'a Law: Islamist Activities and the State in Democratizing Indonesia, London: Cambridge University Press, 2016. 
Capoccia, G., \& Kelemen, R. D. "The study of critical junctures: Theory, narrative, and counterfactuals in historical institutionalism." World Politics, 59, no.03 (2007).

Indrayana, Denny. Indonesian Constitutional Reform 1999-2002: An Evaluation of Constitution Making in Transition, 2005.

Kahin, George Mc Turnan. Nationalism and Revolution in Indonesia, Ithaca NY: Cornell University Press, 1952.
Weatherbee Donald E. Indonesia in 1984: Pancasila, Politics, and Power." Asian Survey 25, no. 2 (1985): 187197.

Weatherbee, Donald E. "Indonesia: Political Drift and State Decay." The Brown Journal of World Affairs, IX, no.1 (2002).

Widjaya. Pendidikan Kewarganegaraan, Bandung, PT RafikaAditama, 2004. 